doi: $10.1515 /$ stap-2015-0010

\title{
ON SOUTH AFRICAN VIOLENCE THROUGH GIORGIO AGAMBEN'S BIOPOLITICAL FRAMEWORK: A COMPARATIVE STUDY OF J.M. COETZEE'S DISGRACE AND Z. MDA'S WAYS OF DYING
}

\author{
RYSZARD BARTNIK
}

Adam Mickiewicz University

\begin{abstract}
In this article I argue that the developments of countries going through transition from authoritarian to democratic rule are always stamped by numerous references to formerly sanctioned and fully operational institutionalized violence. A perfect exemplification of this phenomenon is [post-] apartheid South Africa and its writing. In the context of the above, both the social and the literary realm of the 1990s might be perceived as resonant with Giorgio Agamben's 'concentrationary', deeply divisive imaginary. Escaping from, and concurrently remembering, past fears, anxieties, yet seeking hope and consolation, the innocent but also the formerly outlawed and victimized along [interestingly enough] with [ex]perpetrators exemplify, as discussed in J. M. Coetzee's and Z. Mda's novels, the necessity of an exposure of the mechanism of South African 'biopoliticization' of life. Their stories prove how difficult the uprooting of the mentality of segregation, hatred and the policy of bracketing the other's life as insubstantial, thus vulnerable to instrumental violence, in [post-] apartheid society was. In view of the above what is to be highlighted here is the authorial perception of various attempts at disavowing past and present violence as detrimental to South African habitat. In the end, coming to terms with the past, with the belligerent nature of local mental maps, must inevitably lead to the acknowledgement of guilt and traumatic suffering. Individual and collective amnesia conditioned by deeply-entrenched personal culpability or personal anguish is then construed as damaging, and as such is subject do deconstructive analysis.
\end{abstract}

Keywords: bare life, [post-] apartheid novel, violence, Giorgio Agamben, the other

The South African moment of transition from authoritarian to democratic rule was stamped by the distinct echo of formerly sanctioned and fully operational forms of institutionalized violence. Thus understood violence in its essence can be related to two aspects of apartheid South Africa; namely, the state with its machinery taking unprecedented, often brutal measures to 'neutralize' its 
enemies and counterforces, thus less or more organized resistance, deploying brutal methods of retaliation against both external as well as internal foes. The overwhelming character of deadly violence manifested itself as continuously rising near the end of apartheid, but after its actual collapse the use of it was barely going to level off or decline for several years thereafter. In point of fact, as some claim, the post-apartheid society entered a reformed stage of the old conflict, yet this time even more violent than before. As Mark Shaw indicates, the current predicament was "blamed on 'a culture of violence' which has resulted from years of apartheid brutality, ... lack of respect for others ... and a propensity, given the country's past, to settle disputes violently" (Shaw 2002: 58). Brutal, marked by the paucity of respect for the other, ${ }^{1}$ the South African reality seemed to resonate with images and experiences outlined, albeit in a different, some would say a more horrifying context of the Nazi regime, by Giorgio Agamben. It is through his stance on the state of exception and bare life that some light can be shed on the mechanism of deprivation and violence which also in South Africa showed its sad manifestation. My intention thus is to consider the extent to which the overall apparatus of dispossessing individuals of their civil and ontological substantiality is observable in a [post-] apartheid South Africa, and as such finds its reflection in John Maxwell Coetzee's Disgrace and Zakes Mda's Ways of dying.

The apartheid era, adopting the policy of exclusion, did effectively remodel the consciousness of South Africans. ${ }^{2}$ In order to understand the status of the individual as deprived of personal and political substantiality, and as being exposed to uncompromising and often brutal actions of the dominant and privileged, one needs to look back to the time of apartheid. Its impact on the contemporary South African mind-set is described by Mark Sanders, who pointed out that "... apartheid was a system of enforced separation", and its proponents along with its opponents "found themselves implicated in its thinking and practices" (Sanders 2002: 1). As a result, the frame of apartheid rule and culture must be held responsible for providing delinquent behavioural patterns which laid the ground for "a violent response to, a disavowal of, the other" (Sanders 2002: 189). Locating non-whites on the periphery of public life, the regime in pursuit of its political objectives, supported by a considerable number of 'privileged' citizens, perceived violence as a perfectly acceptable

1 My understanding of 'the other' concurs with Ofelia Ortega's viewpoint, based in turn on Robert Schreiter's theoretical model. In the distinction she makes between the other as "inferior" and the other as "non-individual" the common ground concerns "situations of violence" in result of which the other, seen "not on the same level of humanity as their oppressors", can be deemed inferior and disappear as "in Argentina or Chile" (Ortega 2002: 384).

2 According to Colin Knox and Rachel Monaghan (2002: 8), that acknowledgement of the policy of estrangement continues after the collapse of the regime as the newly established South African authorities were disappointed with deployment of moral standards. 
means of dispossessing people of their basic human rights. This strategy of noninclusion worked so effectively since the underprivileged were categorized as of a lesser substantiality not only on political, but in the first place, on racial grounds. Violence perpetrated against other-than-white citizens of South Africa was seen as being justifiable, if not 'natural', from the very dawn of the apartheid era. As underlined by Shaw, the authorities legitimized "harshness, brutality and racism [as] hallmarks of "law enforcement" (Shaw 2002: xi). In nature of this regime was to stigmatize, exclude, downgrade and oftentimes dispose of anyone appointed to the underclass. Neither surprising nor incomprehensible was it as some normative legal acts of apartheid South Africa were enacted in order to endorse, to use Giorgio Agamben's phrase, the 'biopoliticization' of life.

Since, as Sanders (2002) underlines, everyone has been affected by the belligerent nature of the apartheid regime and its mental map, it seems legitimate to assume that the mechanism of deprivation and violence spread across South African society, thus altering also the mind-sets of the people who opposed or were victimized by the police state. In other words, the relevance of biopolitics cannot be reserved for the accomplices of apartheid rule alone. And with this stipulation in mind, the mechanism of biopoliticization must be applied to the South Africa of the 1990s to imply at large "the threshold beyond which life ceases to be politically relevant, becomes only 'bare life,' and can as such be eliminated". This formula, the way it has been defined by Agamben, can be easily extended to a variety of twentieth-century 'biopolitical' contexts which gained rather unwelcome international notoriety for politicizing "the life of the people". In fact, it goes as far as to assert that "[e]very society sets this limit; every society - even the most modern - decides who its 'sacred men' will be" $^{\prime 3}$ (Agamben 1998: 139, 149). Should this categorization be valid with regard to any modern societies, it is all the more relevant with reference to the [post-] apartheid background.

Employed in relation to South Africa, the notion of the biopoliticization of life, especially in view of the binary logic of apartheid, underscores its salient characteristic, namely the juxtaposition of the empowered and disempowered. Nevertheless, pondering whose life is bare and how it is definable against the backdrop of the indigenous body politic almost seems unnecessary and redundant. It is an undeniable fact that apartheid South Africa is most often positioned as a standard reference point on the policy of segregation, political/cultural discrimination as well as on the ideological and legal means

The sacred man is also defined as the accursed man, thus anyone whose life is worthless enough to be taken away by the entitled. As deprived of legal significance, that life which can be so easily destroyed cannot be subject to religious rituals either. Its value is nonexistent. 
used to define the life of the other as bare. Thus a formulated composite of aggressive mentality and bare life can be thought of as an echo of Agamben's philosophical reflection, and as such is encompassed in the structure of his biopolitical framework. Yet, to argue its applicability one needs to consider two constitutional aspects of his theory. On the one hand, as Leszek Koczanowicz points out, the question of bare life is linked with mechanisms of power by means of which groups or certain broader categories of people become debased, and as a result undergo the interlinked process of "subordination" and "domination" (Koczanowicz 2010: 169). On the other hand, as indicated by Ewa Płonowska-Ziarek, a bare life might be construed as vulnerable, "replaceable" and "threatened" by the mere fact of its "exclusion". And most importantly, seen as vulnerable, that kind of life is always "exposed" in an unprecedented manner to inevitable acts of violence (quoted in Koczanowicz 2010: 170). In the above context, apartheid rule, establishing the lack of balance between human categories - in terms of political and legal regulations sanctioned the legitimacy of claims to domination over the vulnerable, devalued and downgraded.

Since the literary texts in question concern the moment of the collapse of apartheid as well as the succeeding periods of the political transition, it is legitimate to consider whether the culture of bio political segregation and culture of violence, as outlined above, remained intact as processes of democratization progressed. Thus it is crucial to decide to what extent the paradigmatic policy of violation of the other has left its imprint on representatives of some population groups of post-apartheid South Africa. The most general remark would be that even in the aftermath of the demise of the regime tensions were hardly defused. In the Human Rights Watch report of 1995 we can read that the situation exacerbated, and what "preconditioned ... the violence that ... threatened to derail the transition" was "fifty years of rule by government[s] that chose race as the basis of policy" (1995: 58). The [re]intensification of violence seems to have had yet another rationale. As Charles Tilly indicates, violence has this tendency to abruptly force its way into communal life "where and when governments are ineffectual", and the moment of its "proliferat[ion] [takes place] in the populations under the nominal jurisdictions of those governments" (Tilly 2003: 26). It is evident that in the times of crisis, here construed through the lenses of South Africa's groundbreaking political transition, deep-seated antagonisms, power structures, cultural imprints, which in the past contributed to spreading excessive violence, rather than die out had every chance to erupt and dominate the public domain.

The call for defying the apartheid legacy, which spread on the meta-political level nationwide, had relatively limited potential to guarantee or extend the possibility of reconciliation to the realm of individual, everyday lives. Disrespect, resentment, and the need for resorting to force in retaliation for the 
damage suffered prevailed with regard to interpersonal relations. ${ }^{4}$ Under such conditions, the life of the other was still deprived of its value, and as such remained disposable and unworthy, to be thrown away without human dignity and respect. In the past the situation was obvious, the other's right to participate fully in the public realm was negated; his political status was less than insubstantial; to use Judith Butler's words, it was "unreal". 5 Interestingly enough, as Butler indicates, the victimized/unreal "have a strange way of remaining animated and so must be negated again". Therefore, the pattern of violence and exclusion expectedly repeated itself even after the political transformation as the [former] agents of apartheid policy were confronted with "the apparent inexhaustibility of its object" (Butler 2004: 33). Thus, on the one hand, the process of devaluation of non-whites was echoed both in the mind-set and actions of the privileged minority; on the other hand, there was the other who, nurtured on the culture of violence, was wont to resort to violence in acts of reprisal against former aggressors. As I would argue, this tribal policy of feuding was aimed at anyone who, in the new political dispensation was supposed to be [de]categorized due to differences in race, cultural backgrounds, intercommunity beliefs and affiliations or even economic potentials. ${ }^{6}$ The time of change thus, as indicated by Tilly, began to play a part in the [re]intensification of violence. That was the moment when one observes some "activation and reinforcement of boundaries", where "claims ... to represent a certain 'we"” separates [again] "“us' from them"” (Tilly 2003: 75).

To oppose a potential continuation of the policy of exclusion and verify the integrity of human life, it became crucial to delve into the current state of the South African mental landscape. It proved necessary, also among the men of letters, to take a stance on the legacy of violence. Amongst an array of South African novelists dealing with the geography of Agamben's exclusion, one can easily distinguish two: John Maxwell Coetzee and Zakes Mda. In their novels we see two perspectives on how the violent past and the present predicament of

$4 \quad$ The fierceness of the apartheid era has been barely neutralized by its collapse. Mark Shaw sees post-apartheid South Africa as "a nation in need of healing" where the continuation of culture of violence is perceived as the aftereffect of "years of apartheid brutality" manifesting itself in "lack of respect for others ... and a propensity, given the country's past, to settle disputes violently" (Shaw 2002: 58).

5 Butler points at people who "fall outside of the "human", and therefore, as unreal they "suffer the violence of derealization" (2004: 33).

6 This new dimension of violence in democratic South Africa brings attention to some grey areas which obscure a binary recognition of perpetrators and victims. As Foster, Haupt and De Beer indicate among such areas "the matter of horizontal violence" can be distinguished. Much of that kind of violence is related to the wounded by the regime. Within the constricting confines of non-white identification one encounters "necklace murders, the bitter conflicts between hostel dwellers and informal settlements in black townships" (Foster, Haupt \& De Beer 2005: 4). 
biopolitical dispensation was handled. The former highlights a South African world after the collapse of the regime as seen mainly through the eyes of a white man of high social standing; whereas, the latter comes up with a study of a South African world prior to the completion of undemocratic rule as seen largely through the eyes of a black vagabond. Both of them, of course with a certain shift of focus, try to highlight and comprehend the ingrained culture of violence.

Writing Disgrace, ${ }^{7}$ Coetzee made as his protagonist a distinguished professor of literature who, facing allegations of misconduct for his assault on a coloured female student, is eventually compelled to leave the university. One consequence of the official removal is David Lurie's retreat into the wilderness where his daughter has opted for a reclusive life on a remote South African farm. Since the discussion of Agamben's approach concerned general group categories, the first question to be posed here is whether the character of David Lurie can serve as a representative of a certain collectivity, someone whose actions fit within the function of representation. Once the premises of his intellectual isolation and aloofness have been bracketed, what follows is a possible correlation between his personal mind-set and much of the collective consciousness of a white [post-] apartheid South Africa. Consequently, Hanna Arendt's definition of collective responsibility should be summoned up. From her perspective, that kind of responsibility depends on certain pre-existing conditions. Her argument relates to individuals who are "responsible for something [he] has not done, and the reason for [his] responsibility must be [his] membership in a group which no voluntary act of [his] can dissolve". As Arendt further explains, this kind of responsibility "is political". In other words, collective responsibility can be deemed political when "a given community is being held responsible for what has been done in its name" (Arendt 2003: 149). Given that, David Lurie as a man of both institutional and cultural authority, an eminent representative of the well off part of South African society, finally a white yet inert academic, falls outside the category of people entirely above reproach. In that sense his guilt is not apparent, yet his actions and [in] decisions make him subject to vicarious liability. This is "the price" - according to Arendt, "we pay for the fact we live our lives not by ourselves but among our fellow men" (Arendt 2003: 158).

Interestingly, rather than to Professor Lurie's past, the author is oriented towards the nightmares of his present day. In view of the post-apartheid South African life, the introductory chapters can be read as depicting Lurie as a relic of the Agamben's 'state of exception'. He is held fully responsible for raising

7 A similar analysis of Coetzee's Disgrace has been included in my article devoted to John Maxwell Coetzee and Tony Eprile (see Bartnik, 2014), where I try to outline the policy of memory and forgetting in post-apartheid South Africa. The interpretation of Coetzee's novel in the context of Agamben's framework can be regarded as an extended version of the previous discussion, yet from a completely different theoretical standpoint. 
the conditions of both the symbolic and actual appropriation of a young female student/woman. Sanctioned all by himself, without Melanie's consent, unequal relations between the two parties result in Lurie's wrongful usurpation of authority/privilege, with all the hallmarks of statutory, if not forcible rape. His assault on and violation of Melanie's bodily integrity was committed, notwithstanding Lurie's defiant rhetoric, because the perpetrator could use, and in fact abused a position of power to downgrade and compel an individual, woman, student, and finally racial other into unwanted acts of compliance/submission. This act of violence runs parallel with "the violence", as defined by Agamben, which "exercised in the state of exception ... neither preserves nor simply posits law, but rather conserves it in suspending it and posits it in excepting itself from it" (Agamben 1998: 64). Given that, Professor Lurie, as if testing the country's meaningful democratic transition, seems to claim the privilege of locating himself and acting outside the law. By menacing and harassing the student, he obscures the new legal framework, based on justice and respect, by recalling/re-establishing the apartheid tradition wherein he and other like-minded South Africans disdained/took advantage of and inflicted violence on the underprivileged. In the oppressor's hands Melanie turns into an insubstantial figure, made unreal to the level of disrespect and too weak to protest:

\begin{abstract}
At four o'clock ... he is at her flat. She opens the door .... He has given her no warning; she is too surprised to resist the intruder who thrusts himself upon her. When he takes her in his arms, her limbs crumple like a marionette's. ... nothing will stop him. ... All she does is avert herself: avert her lips, avert her eyes. She lets him lay her out on the bed and undress her .... Little shivers of cold run through her; as soon as she is bare, she slips under the quilted counterpane like a mole burrowing, and turns her back on him. Not rape, not quite that, but undesired nevertheless, undesired to the core. As though she had decided to die within herself for the duration ... So that everything done to her might be done.
\end{abstract}

(Disgrace, 25)

Much the same as 'anesthetized' by the pursuit of his own selfishness, the same as undisturbed by ramifications of his misconduct, the next day Lurie is ready and of an untroubled mind to deliver a lecture during which he formulates a definition of usurpation. His conclusions take us back to the above-mentioned concept of appropriation which draws attention to people who "intrude, encroach upon ... take over entirely" (Disgrace, 21). Straightforward as it is, this definition, in its essence, has not been adopted by David Lurie, at least not beyond the formality of his empty declaration. Therefore, later on, in front of the committee convened to examine his case, Lurie in a defiant speech shows a 
general inability to seek and stand up for his accountability. As Judith Herman points out, it is a common tactic among the perpetrators of serious crimes to plunge into "the most blatant denial or the most sophisticated and elegant rationalization" (Herman 1992: 4). Such is the attitude assumed by Coetzee's protagonist, and that is why the members of the committee [which most evidently is to resemble the Truth and Reconciliation Committee], unwilling to be deceived, are also not eager to treat him leniently. As one of its members explains:

I want to register an objection to these responses of Professor Lurie's, which I regard as fundamentally evasive. Professor Lurie says he accepts the charges. Yet when we try to pin him down on what it is that he actually accepts, all we get is subtle mockery. To me that suggests that he accepts the charges only in name....

The wider community is entitled to know ... what it is specifically that Professor Lurie acknowledges and therefore what it is that he is being censured for....

Professor Lurie pleads guilty, but I ask myself, does he accept his guilt or is he simply going through the motions in the hope that the case will be buried under paper and forgotten?

(Disgrace, 50-51)

Locked up within the reigning unresponsiveness to the plight of bare life, he must be given a lesson in order to renounce violence and understand his own indecency. So begins the process of Lurie's transformation from an Agamben man, insufficiently attentive to the vulnerable human condition, to an individual who reaches out to the other's suffering to change the latter's status into the real. For this very reason, Coetzee sets his character at the perfect midpoint between pure violence and benevolence. Right in that spot as if in the mirror, he will comprehend how quickly, in a diametrically changed political situation, one can be tested out as an object of violence and appropriation. This time it is his daughter who falls victim to a brutal assault. Raped and made a part of "noman's-land between public law and political act" (Agamben 2005: 1), she embodies the inexhaustibility of violence in the world driven by the politics of exception. Embedded in such a world and constitutive of men's actions are final decisions concerning who can be considered a 'sacred man', thus whose life can be legitimately disposed of. To rule out the possibility of falling back on the logic of pure biopolitics David Lurie - as one of its vicarious intellectual architects and an actual offender - must hear out how it feels to be usurped upon, how it is to be violated and appropriated, and not only as a human of lesser degree [non-white] but simply as another human being. That is what Lucy, in the following words, tries to highlight: 
Hatred ... nothing surprises me anymore. ... When you have sex with someone strange - when you trap her, hold her down, get her under you, put all your weight on her - isn't it a bit like killing? Pushing the knife in ... leaving the body behind covered in blood - doesn't it feel like murder. ... They spur each other on. That's probably why they do it together. Like dogs in a pack.

(Disgrace, 158)

Her conclusion is uncompromising as she indicates that this predilection for violent retaliation is carried out across a broader South African spectrum. And only this time, a single, yet horrible act of transgression can be construed as a retort of some black people for years of "subjection, subjugation" (Disgrace, 159); or using Agamben's formula, years of devaluation and exclusion. And maybe to avert this tradition of downgrading one needs to internalize the other's state of humiliation, one needs to be humiliated to give up on revenge and to renounce the policy of violence. In the end Lucy asserts: "Perhaps that is what I must learn to accept. To start at ground level. With nothing. Not with nothing but. With nothing. ... no weapons, no property, no rights, no dignity ..." (Disgrace, 205).

While Coetzee thematizes violence in the context of Lurie's rape attempts, concurrently, accounting for the immediate [post-] apartheid era, Zakes Mda studies it in the context of killings, funerals, and mourning on the very eve of democratic transformation. The contemporary South African landscape is marked by the sweeping political changes that have already started or should be considered imminent. Agamben in the State of exception claimed that "during periods of ... crisis, ... social functions and roles break down to the point where [once] conditioned behaviours and customs are completely overturned" (Agamben 2005: 65). The world in transition, as depicted by Mda, does resemble Agamben's world of "anomie" where "order" is replaced by "disorder"; where "the possibility of anomic terror" becomes actual since the well-established regulations have been questioned (Agamben 2005: 66). Nevertheless, thus defined anomic terror should not be considered in contrast to the enhanced stability of the receding apartheid era. It is just another manifestation of the forces of violence endemic in the society that have been moulded by a policy of separateness. As a result, there is no mention of justice being rightly meted out to the individual but rather justice being suspended in order to sanction the suffering inflicted upon that individual whose humanity were to be bracketed.

Unlike Coetzee's character, Mda's protagonist travelling across South Africa is to witness and acknowledge many negative consequences of the aforementioned cultural and political imprint. Although the demise of the apartheid system is looming on the horizon, little has changed in terms of the on-going violence save for a major alteration in terms of its vectors that did 
creep in and can be diagnosed. All things considered, it becomes evident that now representatives of all different ethnicities can undergo victimization depending on who is in power, actual/physical or political, to [de]value an individual life. From the first scene of the book the author immerses us in the commonality of pain and grief conditioned by the spread of violence, resonant in South Africa only months before the end of apartheid. Mda launches his narrative using his eponymous verse which informs that there are many ways of dying. Diverse as these ways are the images of dying of the trapped and underprivileged have one thing in common, namely, a rather inhumane character of all deaths in question. Their inhumane nature is connected with the simple fact that the victims' lives were recognized as meaningless and irrelevant. Most importantly, however, they were killed by people of the same skin colour. They died or were executed due to the status of sacred men whose lives have become bare - paradoxically but rather unsurprisingly - within the same ethnic boundaries, within the realm of the formerly oppressed: "This little brother was our own child, and his death is more painful because it is of our own creation " (Ways of dying, 7).

What has been foregrounded by Mda is the endless proliferation of violence and death nurtured on cross-community decay and disharmony. Under such conditions, it is not uncommon to see groups of people who, unwilling to renounce violent means of domination, considered themselves to be some advocates of the new order entitled to fight some 'festering wounds' on the South African backside. Toloki's journey into the South Africa of the early 1990s clearly indicates not only the commonality of violence and death but also a very permissive and belligerent attitude towards life which can be instantly and brutally ended. Much as the early 1990s are associated with the time of liberation in South Africa, they also indicate a deep anxiety that the looming political change brings to white South Africans. With the crumbling walls of the 'old world', they are expected to readjust their attitude to the upcoming sociopolitical transformations, and in consequence also to racial others. As Njabulo Ndebele underlined, "the laws of perception that have characterized apartheid society" were to be lifted (Ndebele 1994: 7). Nevertheless, it appears evident that not only whites but also non-whites were urged to embrace the humanity of the other and to internalize their respective role and responsibility in actual or potential [re]endorsing the biopolitical mechanism. Therefore, in Mda's novel what constitutes the overall and overwhelming cultural resonance of South Africa is the daily dying, taking place in the immediate vicinity, particularly among people of non-white origins, who are also eager to make a distinction between valuable and less valuable lives and deaths.

In the aftermath of a single massacre we observe a young woman who, looking for her brother, sees the crushing banality of death: 
there were a dozen corpses lying naked on the floor. ... She was led to another room, with more naked bodies on the floor. ... Altogether there were perhaps twenty bodies of old and young men and women, beautiful girls ... lying in grotesque positions, children who were barely in their teens, all victims of the raging war consuming our lives. ... there is death out there.

(Ways of dying, 15)

Yet another fragment draws attention to individuals whose lives were disposed of by those who recognized them as a threat to the community. Theirs is suffering which gains significance as they became actors on the national stage rather than to remain as some shadowy figures on the margins of a South African narrative. From this angle, the notion of Toloki's experience should not be construed as relating only to some dramatic events of marginal significance, for "death and funerals continued to dog his way throughout" (Ways of dying, 66). Mda exposes the negative consequences of the legitimization of violence within the social realm which endorses resorting to violent means for the settling of actual or alleged unfairness. As Toloki recounts, within local communities its members "had come together, and decided to serve their own justice. According to a journalist who wrote about one of such incidents 'it was as if the killing had, in a mind-blowing instant, amputated a foul and festering limb from the soul of the community" (Ways of dying, 66). There can be no denying the obvious conclusion that violence, and rampant violence in particular, was here depicted as damaging to the social fabric of contemporary South Africa.

Taking into account the above scenes, one could develop an understanding of such actions as if they were taken by individuals/groups to safeguard their integrity, to fight a potential threat. Much as inciting such immediate violence can be deemed justifiable in an alleged state of necessity, it undeniably implicates future acts of violence that can be perpetrated on anyone who is to be recognized as capable of unsettling the categorical distinction between 'us' and 'them'. Agamben, elaborating on the mechanisms of deprivation by means of which one can be taken outside, highlighted and defined the above phenomenon as the ability of men in power to make unrestrained decisions concerning the life of the other. ${ }^{8}$ Therefore, from Mda's perspective it is essential to unlearn the paradigmatic use of violence. In the society on the threshold of democratic reform meting out justice cannot be tantamount to taking revenge, and gaining power cannot be synonymous with the [de]categorization of other people, or

8 The above inference is drawn on Agamben's conclusion regarding "a new juridical-political paradigm in which the norm becomes indistinguishable from the exception. ... the structure in which the state of exception ... is realized normally [italics original], [where] the sovereign no longer limits himself" (Agamben 1998: 170). 
else the state of exception will carry on. Mda's novel delivers one of the most memorable lines that feels close enough to a significant aphorism. The phrase "Our ways of dying are our ways of living" - exhibits important correlations between the quality of life and quality of death. In the space where one's existence has been brought down to bare life we are outside the boundaries of what can be regarded as socially or morally acceptable, and as inherently stabilizing. Such disordered reality gives no room for, to use legal formulas, the personal interests of not only the other human being, but simply human beings. Depriving people of their due ontological substantiality, of their 'constitutional' right to dignity, one makes the interests of freedom, respect and self-respect, freedom of conscience irrelevant. Mda, to counter tendencies to deny the recognition of the other's right to the aforementioned rights and interests, circles the character of Toloki, correspondingly, shedding some light on the current society which, driven by the biopolitical codes of the South African culture of violence, remains in a dire condition.

This relational context facilitates the interpretation of one of the following scenes wherein, after another commemorative service held for a dead man, Toloki receives some words of gratitude. An elderly woman addresses him with affection and a sense of desolation: "I particularly invited you because I saw you at another funeral. You added an aura of sorrow and dignity that [one] last saw in the olden days when people knew how to mourn their dead" (Ways of dying, 109). Funerals, and in particular the role played out by Toloki during such services, fulfil the function of articulating the loss of human life and dignity. Central to the understanding of that concern is Michael Humphrey's the concept of mourning. As he indicates, it should be construed as "a ritual structure through which suffering, testimony [and] sentience ... can be approached. Mourning socializes death through ritual participation and public witnessing of loss" (Humphrey 2002: 114). ${ }^{9}$ Of certain significance here is obviously the gravity of personal testimony but equally important is the aura of sentience carried to make one aware of the actual [de]humanization of innocent lives as was happening in South Africa and manifested through such rituals.

Unlike Coetzee, Mda has the inclination to hold political leaders responsible for a potential continuation of the policy of exclusion. In one of the scenes of mourning a "funeral orator" referring to one of the binding political agendas clarifies its menacing character. As he indicates, it is not uncommon to find an ethnic chief who "concoct[s] a non-existent threat to his people, telling them that they are at risk from other ethnic groups in the country. Whereas other leaders are trying very hard to build one free and united nation out of the

9 Describing the phenomenon of mourning as a ritual structure, Humphrey takes as his point of reference a view of Veena Das presented in her essay "Language and body: Transactions in the construction of pain" (1996). 
various races, he thinks he will reach a position of importance by exploiting ethnicity" (Ways of dying, 55). When it comes to the reprisal policy, people must give up on 'spontaneous' actions as they also stem from that tradition which validates an usurpation of the other's life. The novel provides us with two contending models. Of the two one is progressive and constructive, whereas the other is reactive and regressive. Again at a funeral, we see a "consummate statesman" who makes a "conciliatory speech in which he called upon the people to lay down their arms and work towards building a new future of peace and freedom. He called those who had died martyrs whose blood would ... water the tree of freedom". At the opposite pole is the leader of a different ethnic group who wants to see himself still on "the war-path. In his fiery speech he called upon his followers to avenge the deaths of their fathers, mother, brothers and sisters" (Ways of dying, 183).

With neglecting the former's stance and affirming the latter's call, it is inhumane death which continues to be the ultimate and central reference point. As has been already highlighted and must be repeated for the third time, "our ways of dying are our ways of living. Or should I say our ways of living are our ways of dying" (Ways of dying, 98). These two notions are tightly interconnected. The mind-set of war makes life a site of struggle which authorizes violent forms of oppression/aggression towards the other. Conditioned by such circumstances, death comes unexpectedly, brutally and inhumanly. Mourning, on the other hand, becomes an immediate reason for reprisal. This vicious circle, which stems from the fact that one is denied the right to live his life in its full dimension, can be averted providing that the population learns how to grieve over the dead. The repertoire of South African theatre, then, requires a new beginning. In the above context Toloki's conceptual significance cannot be downplayed.

Not only should we perceive the protagonist as Benjamin's 'angel of history', ${ }^{10}$ turned towards the logic of violence, but also as a beacon of lookedfor ethical conduct. This new moral paradigm consists in forsaking the foundations upon which the South African state of exception has been built. With respect to the other, by acknowledging the loss of a given individual, Toloki acts against a world of nameless people upon whom, using Auden's words, their foes inflicted pain, suffering and "their shame was all the worst could wish. [T] hey lost their pride and died as men before their bodies died" (Auden, 2014). ${ }^{11}$ Toloki, himself a victim of community violence, is determined to overcome the legacy of past belligerence by exercising such attributes of his character as compassion and forgiveness. Noria, his female companion, in a succinct evaluation of Toloki's life-choices, expresses the highest approbation

See Walter Benjamin, “On the concept of history” ([1940] 2006).

A fragment from W. H. Auden's poem - The Shield of Achilles (1955). 
of Toloki's fundamental human decency. Her words speak volumes for the path to be chosen out of the state of exception: "You are a beautiful person, Toloki. That is why I want you to teach me how to live. And how to forgive" (Ways of dying, 151). In other words, his legitimacy to hold a leadership role must be connected with nothing else but Toloki's capacity for forgiveness and respect for others.

The prospect of a decent and respected life in transforming South Africa appears of utmost importance, especially with the urgency to include everyone in the new socio-political framework. Its effective implementation is to cure social interactions by curbing any forms of violence directed against all others. Mda is persistent in exposing gruesome details of unlawful punishments meted out to those who have been deemed as deserving 'retribution'. This sharp and uncompromising style implies a concord between Mda's imaginings and the declared intention to eradicate long-held barbarism of inhumane deaths from the South African frame of mind. The reason to narrate a harrowing ordeal, like the one depicted in the following fragment - "Danisa's match fell into Vultha's tyre. It suddenly burst into flames. His screams were swallowed by the raging flames, the crackle of burning flesh, and the blowing wind. He tried to run, but the weight of the tyre pulled him to the ground ... Soon the air was filled with the stench of burning flesh" (Ways of dying, 189), is to indicate that the tendency to brutally appropriate the other's life smoulders in anticipation of post-apartheid recovery. By all means, then, does Mda's detailed presentation of abuse and torment prove his concerns about the unacceptable state of belligerence and his commitment to illuminating the human dimension behind the changing political landscape. Therefore, the ending of his novel once again works upon the symbol of fire. This time, however, it stands not for the 'undignified' deaths of random individuals but rather for a fluorescent and promising beginning with no biopolitical implications:

Somehow the shack seems to glow in the light of the moon .... Crickets and other insects of the night are attracted by the glow. They contribute their chirps to the general din of the settlement. Tyres are still burning. ... The smell of burning rubber fills the air. But ... it is not mingled with the sickly stench of roasting human flesh. Just pure wholesome rubber.

(Ways of dying, 212)

Overall, the adjustment of Agamben's theoretical model to the meanders of South Africa's culture of violence seems by all means valid. As has been indicated in the analysed works of Coetzee and Mda, the society in the moment of transition does experience a major upheaval, often at the expense of basic human values and rights. Furthermore, on the brink of crisis or any fundamental change, people happen to be exposed to - using Agamben's formula - anomic terror. These texts conflate the victims' plight, as described by both authors, 
with the long-standing cultural phenomenon of violence as deeply-seated in the South African landscape. As I have tried to prove, their status may be regarded as resembling the status of the injured parties, of the wounded and dead described by Agamben within only a seemingly distant context of the state of exception. Whether in Europe or South Africa the quality of bare life has been affected with acts of objectification and instrumentalization. Those to be held to account, recognized as products of cultures of violence, had no qualms about the indiscriminate downgrading of the other. Depriving people of their basic freedoms, they acted in the spirit of anomic terror. As both authors seem to have suggested, to navigate a way out of the solidly constructed biopolitical dimension could be considered neither an easy nor a short-term project as it required some painful introspection both on a personal and public level.

\section{REFERENCES}

Agamben, Giorgio. 1998. Homo Sacer. Sovereign power and bare life. Stanford: Stanford University Press.

Agamben, Giorgio. 2005. State of exception. Chicago \& London: Chicago University Press.

Arendt, Hanna. 1970. On violence. New York \& London: HBJ Book.

Arendt, Hanna. 2003. Responsibility and judgment. New York: Schocken Books.

Auden, Wystan Hugh. 2014. The shield of Achilles. http://www.poets.org/poetsorg/poem/shieldachilles (accessed 10 October 2014).

Bartnik, Ryszard. 2014. Frozen thoughts on (post-) apartheid transgressions as conducive to producing new "unsolicited" sprouts of contriteness. Tony Eprile in line with John Maxwell Coetzee on the importance of memory in democratic South Africa. In Bożena Kucała \& Robert Kusek (eds.), Travelling texts: J.M. Coetzee and other writers, 283-295. Frankfurt am Main: Peter Lang.

Benjamin, Walter. 2006. On the concept of history. In Howard Eiland \& Michael W. Jennings (eds.), Walter Benjamin: Selected writings. Volume 4: 1938-1940, 389-400. Cambridge, Massachusetts \& London: The Belknap Press of Harvard University Press.

Butler, Judith. 2004. Precarious life. The powers of mourning and violence. London \& New York: Verso.

Coetzee, John Maxwell. 2000. Disgrace. London: Vintage.

Das, Veena. 1996. Language and body: Transactions in the construction of pain. In Daedalus 125(1), 67-92.

Foster, Don, Paul Haupt \& Maresa De Beer. 2005. The theater of violence. Narratives of protagonists in the South African conflict. Cape Town: HSRC Press.

Herman, Judith. 1992. Trauma and recovery. New York: Basic Books.

Human Rights Watch. 1995. Slaughter among neighbors. The political origins of communal violence. New Haven \& London: Yale University Press.

Humphrey, Michael. 2002. The politics of atrocity and reconciliation. London \& New York: Routledge. 
Knox, Colin \& Rachel Monaghan. 2002. Informal justice in divided societies. Northern Ireland and South Africa. Houndmills, Hampshire \& New York: Palgrave Macmillan.

Koczanowicz, Leszek. 2010. Po takiej wiedzy, jakie przebaczenie? Totalitaryzm, egzystencja, emancypacja [After such experience, what forgiveness? Totalitarianism, existence, emancipation]. In Łukasz Musiał, Mikołaj Ratajczak, Krystian Szadkowski \& Arkadiusz Żychliński (eds.), W sprawie Agambena. Konteksty krytyki [On Agamben. Contexts and critiques], 155-180. Poznań: Wydawnictwo Poznańskie.

Mda, Zakes. 1995. Ways of dying. New York: Picador.

Ndebele, Njabulo. 1994. South African literature and culture. Rediscovery of the ordinary. Manchester \& New York: Manchester University Press.

Ortega, Ofelia. 2002. Conversion as a way of life in cultures of violence. In Raymond Helmick \& Rodney Petersen (eds.), Forgiveness and reconciliation. Religion, public policy and conflict transformation, 362-383. Philadelphia \& London: Templeton Foundation Press.

Płonowska-Ziarek, Ewa. 2010. Strajkujące nagie życie: Uwagi o biopolityce rasy i gender [Bare life on strike: Notes on the biopolitics of race and gender]. http://www.praktykateoretyczna.pl/ewa-plonowska-ziarek-strajkujace-nagie-zycieuwagi-o-biopolityce-rasy-i-gender/ (accessed 09 October 2014).

Sanders, Mark. 2002. Complicities. Durham \& London: Duke University Press.

Shaw, Mark. 2002. Crime and policing in post-apartheid South Africa. Transforming under fire. London: Hurst \& Company.

Tilly, Charles. 2003. The politics of collective violence. Cambridge: Cambridge University Press. 